
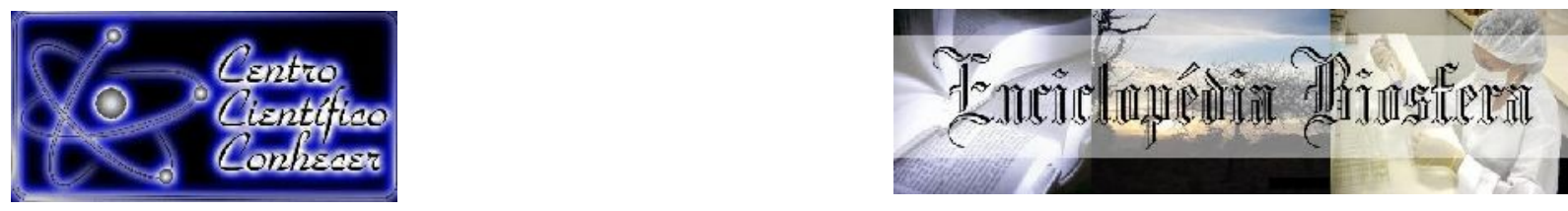

GASTRIC VOLVULUS DILATATION SYNDROME IN DOGS

José Eduardo de Oliveira_, Talliana Cabral Gouveia², Tales Dias do Prado², Tiago Luis Eilers Treichel ${ }^{4}$

1 Student in Veterinary Medicine at the University of Rio Verde (UniRV), Rio Verde-GO, Brazil. E-mail: zezinho25oliveira@hotmail.com

${ }^{2}$ Bachelor of Veterinary Medicine from the University of Rio Verde (UniRV), Rio Verde$\mathrm{GO}$, Brazil.

${ }^{3}$ Professor of the Veterinary Medicine course at the University of Rio Verde (UniRV), Rio Verde-GO, Brazil.

Recebido em: 15/11/2020 - Aprovado em: 15/12/2020 - Publicado em: 30/12/2020 DOI: 10.18677/EnciBio_2020D19

\begin{abstract}
Gastric volvulus dilatation syndrome is a serious condition, of an acute nature, that mav lead to a high death rate in small animals. The etiology is unknown, but the literature reports several treatment possibilities. Gastric volvulus dilatation causes a severe decrease in tissue perfusion, affecting several organs, including the respiratory and cardiovascular systems. This study aims to conduct a literature review on the pathophysiology of this syndrome and the therapeutic approach from patient stabilization to surgery treatment.
\end{abstract}

KEYWORDS: dogs, gastric twist, treatment.

\title{
SÍNDROME DA DILATAÇÃO VÓLVULO GÁSTRICA EM CÃES
}

\section{RESUMO}

A síndrome da dilatação vólvulo gástrica é uma afecção grave, de caráter agudo, que pode resultar em alto índice de óbito em pequenos animais. A etiologia é desconhecida, porém a literatura relata diversas possibilidades de tratamento. A dilatação vólvulo gástrica causa grave diminuição na perfusão tecidual, afetando vários órgãos, incluindo os sistemas respiratório e cardiovascular. Este estudo tem como objetivo realizar uma revisão de literatura sobre a fisiopatologia desta síndrome e a conduta terapêutica desde a estabilização do paciente até o tratamento cirúrgico.

PALAVRAS-CHAVE: cães, torção gástrica, tratamento.

\section{INTRODUCTION}

The gastric volvulus dilatation syndrome (GVD) is an acute clinical condition that constitutes a severe medical and surgical emergency, with a high death rate in dogs, requiring immediate intervention (SILVA et al., 2018). According to Ortiz et al. (2016), this disease occurs mainly in deep-breasted breeds. It commonly occurs in large breed dogs, such as Akita, Collie, Irish Setter, Rottweiler, Standard Poodle, Weimaraner, Great Dane, Irish Wolfhound, Newfoundland, São Bernardo, Great Dane, German Shepherd, São Bernardo, Doberman, Pinscher and Gordon Normatizer (Simpson, 2017; UZAL et al., 2016). The incidence of GVD in these breeds is $6 \%$ and represents $16 \%$ of all causes of death (PINTO FILHO et al., 2015). Although almost all cases are reported by dogs, this is a disease that also affects cats, in rare episodes reported (UZAL et al., 2016). 
The stomach rotates clockwise, completely preventing the emptying of gastric contents, through the esophagus and duodenum, thus progressive air distension occurs (SILVA et al., 2018). Regardless of the degree and type of rotation, GVD results in increased intra-abdominal pressure causing a decrease in blood flow from the caudal and portal vena cava, which impairs venous return, cardiac output and blood pressure, and also compromises tissue perfusion, causing hypovolemic shock (GADDINI et al., 2018).

The etiology is not well understood, but it is believed that excessive feeding, postprandial activity and aerophagia are the main causes of this condition, there is a higher incidence in males and in middle-aged or elderly animals (SILVA et al., 2018).

The rapid diagnosis, the choice of appropriate therapy and early stabilization of the patient are the main factors of a successful treatment (SILVA et al., 2012). Gastropexy is an extremely important technique that aims at permanent adherence of the stomach to the abdominal wall (PINTO FILHO et al., 2015).

According to Gomes et al. (2017) there are reported cases of splenic torsion without a history of gastric and splenic disease, and also without evidence of gastric dilation or torsion. Gomes et al. (2017) also reported a study that corroborates this idea by identifying a significant correlation between dogs affected with splenic torsion and who had episodes of gastric dilation syndrome months before the presentation of the splenic alteration.

The aim of this study is to perform a systematic review addressing the anatomy, physiology, physiological changes that this syndrome can promote, as well as changes in laboratory tests and how to reach the diagnosis of GVD. It also describes about surgical techniques to correct the malposition of the organs affected, including weightings on anesthetic drugs.

\section{Anatomy and Physiology}

\section{LITERATURE REVIEW}

The simple stomach that makes up the digestive system of dogs is anatomically divided into cardia, fundus, body, den and pylorus. The cardia delimits the entry of the intra-abdominal esophagus into the stomach and consists primarily of mucous cells for lubricating the ingested content. The fundus is located dorsally to the left of the cardia, the foods first fill the fundus and later the body, which is the largest region of the stomach and consequently has the greatest capacity for expansion (PEREIRA; FANTE, 2019; WILLIAMS, 2015). The antrum is the distal region of the stomach, it consists of mucous cells and gastrin secreting cells, it acts on mechanical digestion, fractioning the solid portion (KÖNIG, 2016). And finally the pylorus acts as a ligament between the stomach and the duodenum, controlling gastric emptying and preventing duodenal reflux. (PEREIRA; FANTE, 2019; WILLIAMS, 2015).

The stomach is bag-shaped and positioned transversely between the lower esophageal sphincter and the pylorus. It is located to the left of the Alba line, in a transversal plane, and it is stable (KÖNIG , 2016).

It acts as a reservoir for food in the initial stages of digestion, being responsible for the action of grinding or crushing the large particles, making them smaller so that they flow easily through the pylorus. Due to the $\mathrm{pH}$ of 2 to 3 of the stomach, the concentration of microorganisms in the gastric lumen is negligible, minimizing the risk of septic peritonitis when compared to intestinal surgery (ELLISON, 2015).

\section{Gastric Dilatation Syndrome}

The gastric valve dilation syndrome must be distinguished from postprandial engorgement ("food tympanism"), which is characterized by the consumption of a large amount of food, resulting in an excessively distended stomach and full of content in a normal position (SILVA et al., 2012). 
According to Williams (2015), a series of subacute pathophysiological changes occur simultaneously and are responsible for the high rate of death. The sequence of events and etiopathogenesis are not completely understood, and several local and systemic pathophysiological effects expose the animal to an imminent risk of death (SILVA et al., 2012).

Among the triggering factors, there is the chest conformation with deep chest, loosening of the hepatoduodenal and hepatogastric ligaments, postprandial exercise, food composition, obtaining the food placed in a higher place, stressed temperament, age, sudden ingestion of a large volume of food, first-degree kinship with a previous history of GVD and increased production or ingestion of gastric gas (NELSON; COUTO, 2005; PEREIRA; FANTE, 2019). Hammer and Grand (2019) reported the occurrence of this pathology in a 5-month-old Bernese Mountain Dog (Bernese Mountain Dog), which contrasts with the information found in other studies, which normally links SVGD to senile animals.

Silva et al. (2018) point out that the act of eating once a day, quickly and being male are other predisposing factors to trigger this clinical condition. While Uzal et al. (2016) point out that Pneumonyssoides caninum infection, which causes reverse sneezing, may be a risk factor for the occurrence of GVD.

GVD rarely occurs in small dogs, its main occurrence is in large and giant dogs with deep chest (NELSON; COUTO, 2005).

In gastric volvulus dilation syndrome, distention of the stomach occurs due to the accumulation of gases, liquid or ingested material, associated with mechanical or functional obstruction of the pylorus (LEVINE; MOORE, 2009). Although aerophagia is believed to be the most likely source, the origin of air accumulation is not known for certain. Generally, air is ingested when the food or water is swallowed. Excited, stressed dogs or even those that ingest food quickly, can swallow an even greater amount of air (SILVA et al., 2012).

According to the distention of the stomach, the pylorus is moved from right to left on the floor of the abdominal cavity, positioning dorsally to the left side (WILLIAMS, 2015). Normally, gastric dilation precedes the volvulus, although there are rarely reports without dilation, suggesting that it cannot be considered the only prerequisite that establishes this condition (SILVA et al., 2012).

In dogs with GVD, clockwise rotation is the most commonly observed. The degree of rotation is determined by the deviation of the longitudinal axis through the pylorus and cardia in the median sagittal plane and is usually between 270 and $360^{\circ}$. If the rotation is less than 180', it will be called "torsion" and, if it is higher, it will be called volvulus (SILVA et al., 2012). If the stomach twists completely, the gastric flow is obstructed, causing progressive gas distension (NELSON; COUTO, 2005).

Clockwise displacement begins with rotation of the pylorus and antrum, from the right abdominal wall to the ventral midline. Thus, the pylorus and the antrum pass over the bottom and body towards the left abdominal wall, which subsequently pass under the pylorus and antrum, towards the ventral midline and right abdominal wall (SILVA et al., 2012; UZAL et al., 2016).

According to Silva et al. (2012), the stomach is closely linked to the spleen by the gastroesplenic ligament. Thus, depending on the degree of gastric torsion, splenic torsion can occur simultaneously (NELSON; COUTO, 2005). The spleen suffers from congestion due to the rotation and obstruction of its vessels and the stomach secondary to torsion and occlusion by compression of the portal vein, resulting in splenomegaly and arterial involvement (SILVA et al., 2012). In most cases, the congested and enlarged spleen returns to normal color and dimensions immediately after its return to the anatomical position. Splenectomy before repositioning is indicated only in cases of venous thrombosis or splenic necrosis. Repositioning in cases of necrosis is contraindicated, as it releases a series of factors or vasoactive mediators, which will 
completely compromise the systemic circulation (SILVA et al., 2012).

It has been studied that the occurrence of repeated episodes of gastric dilation and consequent partial torsion of this organ promote the stretching and loosening of the gastroesplenic ligaments, causing mobility and splenic rotation in addition to gastric changes (GOMES et al., 2017).

\section{Gastric and splenic pathophysiology}

The pathological changes that occur in the stomach can vary from hemorrhage and moderate edema to necrosis of the entire organ. This occurs due to torsion or even the volvulus occluding and compressing the short gastric arteries that supply the greater curvature and the bottom of the stomach (WILLIAMS, 2015). This phenomenon leads to a severe decline in the concentration of oxygen on the stomach surface, with a marked reduction in blood flow, resulting in ischemia (SILVA et al., 2012), and subsequently necrosis of large areas of the stomach and consequent rupture and leakage of gastric contents to the abdominal cavity (WILLIAMS, 2015).

There are several factors that lead to gastric ischemia, among them, transmural hypertension, obstruction of the venous outlet, ischemia of micro vascularization, mural edema, reduction of cardiac output (with consequent decrease in pressure and arterial perfusion). The excess of gas and liquid in the stomach of dogs with GVD increases intragastric pressure that causes venous stasis and congestion, which will cause disorders in blood flow (SILVA et al., 2012).

During gastric torsion, the spleen also dislocates with greater curvature, which can cause splenic ischemia and necrosis, due to impaired vascularization (WILLIAMS, 2015). The increase in portal pressure decreases the activity of Küpffer cells, which act in the elimination of bacteria and endotoxins. Bacterial translocation occurs and, in sequence, vascular collapse, disseminated intravascular coagulation (ICD) and septicemia may occur (UZAL et al., 2016). There are mild or severe increases in serum concentrations of alanine transaminase (ALT) and alkaline phosphatase (FA), due to congestion and ischemia-reperfusion injury (SILVA et al., 2012).

\section{Respiratory pathophysiology}

It is clear that the primary effects of gastric distension compress the diaphragm, limiting its expansion and consequently decreasing the lungs' functional reserve capacity. This phenomenon results in alveolar hypoventilation, which causes changes in the ventilation / perfusion ratio and arterial hypoxemia, which leads to breathing difficulties (WILLIAMS, 2015). Through hypoventilation, the animal develops respiratory acidosis, secondary to a decrease in ventilatory compliance (GALVÃO et al., 2010).

If there is obstruction of the caudal and portal veins, there is a reduction in venous return to the right ventricle, thus, less blood volume will be available for oxygenation in the lungs (SILVA et al., 2012).

\section{Cardiovascular pathophysiology}

Gastric dilation promotes direct mechanical compression over the portal and caudal vena cava. This compression has a double effect, considerably decreasing venous return and resulting in portal hypertension (PEREIRA; FANTE, 2019). This compression also induces edema, congestion and damage to oxygenation of the gastrointestinal tract, in addition to reducing vascular volume and compromising microcirculation in the viscera (GADDINI et al., 2018).

Decreased venous return to the heart reduces cardiac output, systemic arterial pressure and mean pulmonary arterial pressure. As a compensatory mechanism, the patient has tachycardia, tachypnea, arrhythmia, rapid hypokinetic pulses, decreased pulse pressure and urinary output, developing hypovolemic shock, due to the restriction of venous return and metabolic acidosis (SILVA et al., 2012) These vascular changes 
promote hypoxia of several organs, mainly the myocardium and the pancreas, leading to the deviation of anaerobic metabolism, initiating lactic acidosis that can become accentuated, occasionally resulting in multiple organ failure (GADDINI et al., 2018) .

Secondarily to myocardial ischemia, acidosis and reperfusion injury, there is a reduction in contractility, contributing to depression and cardiac dysfunction, thus reducing systemic blood flow and perfusion pressure (SILVA et al., 2012).

\section{Reperfusion injury}

This event occurs when there is a temporary interruption of blood distribution to tissues and its reperfusion triggers a series of catastrophic events, causing an increase in the production of reactive oxygen species (free radicals), necrosis, damage to the vascular wall and increased mucosal permeability (SILVA et al., 2012).

Cellular hypoxia, in addition to triggering metabolic acidosis, affects the ion gradient, causing the elevation of calcium ions in the intracellular environment. Thus, the cell membrane breaks and the rapid conversion of the enzyme xanthine dehydrogenase to xanthine oxidase (WILLIAMS, 2015).

Immune mediators are produced and invade the circulation, initiating a systemic immune response, injuring numerous organs. During reperfusion of the ischemic stomach and other splanchnic organs, tissue damage occurs due to the blood's inability to flow through previously ischemic capillaries and the action of oxygen-derived free radicals (SILVA et al., 2012).

\section{Disseminated intravascular coagulation (ICD)}

Disseminated intravascular coagulation (ICD) is a secondary phenomenon with a multifactorial etiology. Due to the reduction of tissue perfusion, the formation of several microthrombi occurs, which occlude the vascular lumen, promoting even more tissue hypoxia and consequently ischemia of the organs. The diagnosis of DIC is based on the prothrombin time (PT) and the increase in activated partial thromboplastin (aPTT) associated with the presence of fibrin degradation products (PDF), however these tests are only available in specialized laboratories (RADLINSKY, 2014; WILLIAMS, 2015).

\section{Renal pathophysiology}

The kidneys have the function of limiting the effects of reduced perfusion, through the local production of prostaglandins E2 and 12 . The function of these prostaglandins is to make vasoconstriction of the afferent vessels. However, this mechanism is ineffective if perfusion is not corrected due to abnormal circulatory pressure. There is a decrease in the glomerular filtration rate, with resulting oliguria, however, if the change in perfusion persists, the nephrons may be affected and the patient may develop acute renal parenchymal insufficiency secondary to the injury (RASMUSSEN, 2007; WILLIAMS, 2015).

\section{Glucose abnormalities}

In VGD, glucose production is increased due to the release of catecholamines, which changes from aerobic to anaerobic because of tissue perfusion. The anaerobic pathway is less efficient, consuming a high glucose index, thus the available glucose becomes reduced, due to liver congestion and low perfusion, hypoglycemia in this case indicates an unfavorable prognosis (WILLIAMS, 2015).

\section{Effects on other organs of the abdominal cavity}

The spleen reduces venous distribution, causing splenic congestion, thrombosis and subsequently necrosis. In the intestine there is edema, hemorrhage and lesions in the intestinal mucosa, due to infusion injury. And the pancreas has tissue edema and necrosis (RADLINSKY, 2014). 


\section{Clinical signs}

The clinical signs are not very evident, however the animal may present abdominal distension and discomfort, tympanic to percussion; mimic of vomiting; ptialism; unproductive vomiting; apathy and prostration; capillary perfusion time (CPT) increased; circulatory collapse (weak peripheral pulse and tachycardia and compensatory), associated with hypotension and hyperemic mucous membranes; dyspnea due to compression of the diaphragm, in non-compensatory shocks, patients may experience hypothermia (SIMPSON, 2017; WILLIAMS, 2015).

\section{Diagnosis}

The presumptive diagnosis is based on the animal's history, physical examination findings associated with radiographic examinations and blood sample collections. The exams are useful in the continued management, but stabilization of the patient is essential (PEREIRA; FANTE, 2019; WILLIAMS, 2015).

Clinical signs alone do not distinguish between simple dilation and gastric volvulus dilation syndrome. The main difference between simple dilation and the volvulus is that in the simple there is no anatomical malposition of the stomach (RADLINSKY, 2014).

\section{Laboratory Diagnosis}

Laboratory findings are not pathognomonic for GVD, however they represent the patient's general condition at the time of care, unless the patient develops disseminated intravascular coagulation causing thrombocytopenia (GALVÃO et al., 2010; PEREIRA; FANTE, 2019; WILLIAMS, 2015 ).

The patient may present a stress leukogram with leukocytosis associated with lymphopenia, which may progress to a reduction in the nuclear polymorph count, worsening the patient's condition (PEREIRA; FANTE, 2019).

Although the potassium concentration may be normal or increased, it is more common to find hypokalemia (RADLINSKY, 2014). However, when metabolic acidosis is established, it is possible to find hyperkalaemia (SILVA et al., 2018).

According to Williams (2015), although the test is not entirely available, the measurement of perioperative lactate plasma concentrations has been shown to be an excellent indicator of gastric necrosis and determined the poor prognosis of patients with GVD (GADDINI et al., 2018).

\section{Radiographic diagnosis}

The radiographic exam is used to confirm the clinical diagnosis, and to help differentiate between simple gastric dilation and gastric volvulus dilation syndrome (GALVÃO et al., 2010).

Radiography is a useful tool, but it is not essential. Suspected patients should not be radiographed until they are stabilized and the benefits must outweigh the risks involved with the procedure (WILLIAMS, 2015). Gastric decompression should be performed on animals that develop GVD in advance of radiographs (RADLINSKY, 2014). Right or dorsoventral lateral projection is used for better visualization (GALVÃO et al., 2010).

In the right lateral radiographic observation of a dog with GVD, the pylorus is found cranially to the gastric body and remains separated from the rest of the stomach by soft tissue (reverse C sign) (RADLINSKY, 2014), dorsally in the gastric shadow with gas (WILLIAMS , 2015).

In the dorsoventral view, the pylorus is filled with gas, to the left of the midline (RADLINSKY, 2014). There may be compartmentalization of the stomach in the lateral view and splenomegaly (RADLINSKY, 2014; SIMPSON, 2017). 
The presence of peritoneum pneumonia suggests gastric rupture and requires immediate surgical intervention (GALVÃO et al., 2010). According to Williams (2015), it is associated with a higher mortality rate.

According to Rasmussen (2007), the radiological signs are: a very distended stomach, filled with gas filling almost the entire abdomen. Normally, a fold of the gastric wall may be seen in the lateral view crossing the distended stomach, representing the division between the compartments of the twisted stomach. The pylorus is displaced dorsally, cranially and to the left, its recognition in the abnormal position helps the differentiation between torsion and simple dilation. The intestine flows caudally, and may contain large amounts of gas. Splenomegaly occurs and the spleen is displaced to the right to varying degrees, but it is usually difficult to identify. The liver and vena cava are smaller than usual due to impaired venous return.

\section{Surgical diagnosis}

The surgical diagnosis of GVD is determined by the position of the greater omentum and the displacement of the pylorus (WILLIAMS, 2015). In an anti-clockwise twist accompanied by simple dilation, the pylorus is located on the right side of the dog's abdomen. The pyloric displacement, in a plane located deep in the cardia, indicates the twist in an anti-clockwise direction, while the position of the superficial pylorus in the cardia, suggests simple dilation. On surgical occasion, some dogs present with normal gastric positioning, due to stomach replacement after perioperative gastric intubation and lavage (RADLINSKY, 2014; RASMUSSEN, 2007).

\section{Differential diagnosis}

It is extremely important the differential diagnosis of gastric valve dilation syndrome of a simple distention due to excess food, or any other diseases that cause abdominal distention (WILLIAMS, 2015).

Simple gastric dilation occurs commonly in young dogs due to excessive food intake and rarely requires specific treatment, as the stomach is not twisted and is also not badly positioned. The small intestine volvulus is a differential diagnosis, as it presents a tympanic abdomen with an extremely increased size; however, intestinal dilation becomes apparent on radiographs. Primary splenic torsion causes acute abdominal pain; however, gastric distension will rarely occur, if distension occurs it will usually be mild. Diaphragmatic hernia shows clinical signs identical to those of GVD, especially if the stomach is herniated and the flow is obstructed (RADLINSKY, 2014).

\section{Clinical treatment (stabilization)}

The initial objective is to stabilize the patient, performing gastric decompression through gastrocentesis, using the largest caliber no. 1416 or18G, on the right or left side, of the region with the highest degree of tympanism to percussion (SILVA et al., 2012).

Simultaneously, two veins (both cephalic and/or jugular) must be accessed with a larger caliber catheter to perform shock therapy with fluid therapy to increase venous return to the heart, increasing cardiac performance and tissue perfusion (RADLINSKY, 2014; WILLIAMS, 2015). This will later assist in the restoration of renal function and the respiratory system (WILLIAMS, 2015).

The combination of crystalloid fluids and colloids is significantly more effective, since colloids have a prolonged effect, increasing oncotic pressure and, consequently, potentiating the effects of crystalloids (WILLIAMS, 2015).

They should be administered at an initial rate of 85 to $90 \mathrm{ml} / \mathrm{kg}$, during the first 30 to 60 minutes. The speed of administration and the volume of fluid administered can be adjusted according to the evaluation of several clinical parameters of the patient, such as (heart rate, peripheral pulse, coloration of mucous membranes, capillary filling time 
and with the measurement of central venous pressure, arterial blood pressure, hematocrit, and total solids (RADLINSKY, 2014).

Fluid therapy with $7 \%$ hypertonic solution ( $5 \mathrm{~mL} / \mathrm{kg}$ for up to 15 minutes), hetamyl (up to $10 \mathrm{~mL} / \mathrm{kg}$ for up to 15 minutes), or a mixture of $7.5 \%$ saline and hetamyl ( $4 \mathrm{~mL} \mathrm{~kg}$ ) for five minutes) (PEREIRA; FANTE, 2019; RADLINSKY, 2014). Hypertonic saline has been successful in shock induced by VGD. Then, crystalloids should be administered at a rate of $20 \mathrm{ml} / \mathrm{kg} / \mathrm{h}$ (WILLIAMS, 2015). The administration of fluids through the saphenous vein will be ineffective in restoring circulatory vascular volume, due to the decreased venous return caused by gastric obstruction to the vena cava (WILLIAMS, 2015).

After infusing high volumes of fluids, it is essential to ensure that urine has been produced (WILLIAMS, 2015) by placing a urethral tube to monitor urine output as an indication of tissue perfusion. Urine output should represent at least 0.5 to $1 \mathrm{ml} / \mathrm{kg} / \mathrm{h}$ (WILLIAMS, 2015). For the stabilization of lisosomal membranes and endotoxemia, administration of coticosteroids, such as dexamethasone phosphate $4 \mathrm{mg} / \mathrm{kg}$ or predinisone sodium succinate 20mg/kg (PEREIRA; FANTE, 2019).

Administer antibiotics preferably with intravenous, bactericidal applicability and with a broad spectrum of action. Amoxicillin with potassium clavulanate (15 to $25 \mathrm{mg} / \mathrm{kg}$ ), cefazolin (20 mg / kg) every 8 hours, represent effective choices (WILLIAMS, 2015). Pereira and Fante (2019) also mention the association of metronidazole with enrofloxacin in addition to the previous options.

\section{Antiarrhythmic therapy}

The arrhythmias most commonly found are premature ventricular contraction (PVC) and ventricular tachycardia (VT). They can be identified and distinguished early after treatment, but they usually start in the trans or postoperative period (WILLIAMS, 2015).

Antiarrhythmic drugs are indicated only if CVP's interfere with cardiac output. In the electrocardiographic tracing, if more than 20 CVP's are observed, or in ventricular tachycardia, the heart rate is equal to or later than 160 beats per minute, treatment should be instituted. A slow bolus of lidocaine $(2$ to $4 \mathrm{mg} / \mathrm{kg}$ ) should be administered, repeated if the sinus rhythm does not recover; continuous infusion of lidocaine (25 to 75 $\mu / \mathrm{kg} / \mathrm{min}$ ) in an attempt to maintain a normal rhythm. Ideally, the level of potassium should be measured before the administration of lidocaine, as it is ineffective, if the patient is hypokalemic (WILLIAMS, 2015).

\section{Gastric decompression}

According to Carrillo et al. (2016), there are three ways to perform gastric decompression: gastric intubation, percutaneous exchange of the stomach and gastrostomy.

With the animal sedated, an orogastric tube must be inserted to complete the removal of gases and remnants of gastric contents (SILVA et al., 2012). With the dog seated, the probe should be measured from the snout, to approximately the eleventh rib in the xiphoid process (WILLIAMS, 2015). Try to pass the probe to the measured point. Thorough care to avoid perforating the esophagus in vigorous attempts to pass the tube, if these attempts fail, a percutaneous decompression of the stomach should be attempted. This attempt will relieve pressure on the cardia and allow the probe to enter the stomach. With the air removed, gastric lavage is performed with saline $(0.9 \%)$ or heated lactate ringer (WILLIAMS, 2015).

The observation of blood in the fluid coming from the stomach justifies an immediate surgical intervention, as it may indicate early gastric necrosis (RADLINSKY, 2014). Due to the high risk of aspiration pneumonia, it is extremely important that the patient is intubated during the procedure (SILVA et al., 2012). A successful orogastric 
tube does not rule out the possibility of gastric volvulus (WILLIAMS, 2015).

There is controversy about the appropriate time to perform the definitive surgery. Immediate surgery (within two to six hours after presentation) is recommended by some authors. Others advocate periods of temporary stabilization with a maximum time of 2-3 hours to perform gastric decompression, because the VGD imposes risks on the viability of the gastric wall (CARRILLO et al., 2016).

\section{Anesthesia}

After adequate stabilization of the patient, anesthesia must be induced and maintained, with agents that have minimal effects on the cardiovascular system. Neurolepto-analgesic and narcotic agents are suitable for both preoperative sedation and anesthetic induction. Methadone $(0.25$ to $0.5 \mathrm{mg} / \mathrm{kg})$ is an effective opioid for preanesthetic medication (MPA), as it has longer analgesia and potential sedative effect (WILLIAMS, 2015). For Bruchim and Kelmer (2014), opioids are acceptable drugs for the function of analgesia, and in addition to methadone, they can also use morphine, buprenorphine, meperidine, hydromorphone and fentanyl. Another protocol that can be associated, as they are synergistic drugs, is lidocaine or ketamine in continuous infusion, in order to reduce the dose of opioids.

Phenothiazines and ultra-fast barbiturates are contraindicated due to their hypotensive, arrhythmogenic effects, and respiratory depressants. Isofluorane or sevoflurane are the inhalational agents of choice, as it produces less cardiovascular depression compared to halothane, enfluorane or thiobarbiturates. If the animal has already been decompressed, is stabilized and there are no cardiac arrhythmias, it may receive intravenously hydromorphone and diazepam and undergo anesthetic induction with thiobarbiturate or propofol etomidate (RADLINSKY, 2014). If the animal is depressed, it probably will not need pre-medication, however oxymorphine and diazepam can be used alone for induction. Perform pre-oxygenation followed by a rapid induction of ketamine and benzodiazepine (midazolam, diazepam) or etomidate (RADLINSKY, 2014).

\section{Surgical treatment}

The objective is to promote gastric emptying, when the orogastric tube is not successfully passed, reposition the rotated stomach, perform gastropexy and determine gastric and splenic viability (SILVA et al., 2012).

The patient should be placed in the supine position and the abdomen should be prepared for midline abdominal laparotomy (RASMUSSEN, 2007). The direction of the gastric valve should be immediately identified. The presence of the greater omentum covering the stomach suggests clockwise rotation, but it must be confirmed by palpation of the gastroesophageal junction. The stomach must be carefully anatomically repositioned in the correct direction, to avoid perforation in devitalized areas (WILLIAMS, 2015). It should be turned in the opposite direction, holding the pylorus (usually found below the esophagus) with the right hand and the greater curvature with the left. Push the greater curvature, or the bottom, of the stomach towards the table while simultaneously lifting the pylorus towards the incision (RASMUSSEN, 2007).

If gastric necrosis occurs, partial gastrectomy, resection and suture should be performed. The invagination technique is contraindicated due to the risk of severe bleeding (SILVA et al., 2012). Assess whether the spleen is normally positioned in the left abdominal quadrant. Total splenectomy must be performed in cases of splenic necrosis or significant ischemia (RASMUSSEN, 2007).

Remove necrotic gastric tissues. Assess whether there is a twist in the gastroesplenic ligament, before suturing, palpating the intra-abdominal esophagus to ensure that the stomach is in the correct position (RASMUSSEN, 2007). Thus, in order to avoid recurrences of GVD, gastropexy should be performed. This event can be done 
by means of incisional techniques, in the form of a belt, circumcostal (dorsal to the rib) and gastropexy by tube using the practical Foley tube in providing enteral access for nutrition and subsequently allows gastric decompression in case of post-dilation operative. These techniques are quick to perform and create very resistant fixation and adhesion (SILVA et al., 2012).

\section{Gastric and splenic viability}

After repositioning the stomach, the viability of the stomach and spleen must be assessed (WILLIAMS, 2015). In several cases, the congested spleen (with a dark red or bluish color) returns to normal color and sizes a few minutes after its anatomical replacement. Splenectomy is indicated only in cases of occurrence of splenic necrosis secondary to avulsion or vascular ischemia (RASMUSSEN, 2007).

Approximately $10 \%$ of dogs have devitalized gastric wall, requiring immediate surgical treatment. It can be difficult to determine the extent and location of the ischemic lesion and gastric necrosis (WILLIAMS, 2015). In relation to the frequency of postoperative complications associated with both the surgical and clinical treatment of stomach necrosis, it is of utmost importance to determine gastric viability. There are no consistent objective techniques for the operative evaluation of ischemic gastric injury. Gastric viability is partially determined in the staining and perfusion of the serosa, viability of the serous vessels, and in the palpation of the gastric wall (RASMUSSEN, 2007). According to Rasmussen (2007), the mortality rate increases when gastrectomies are needed.

\section{Stomach fixation techniques}

To ensure that the stomach is in its normal location and to prevent recurrence of the gastric valve, the pyloric antral region is fixed to the adjacent right abdominal wall, either by the circumcostal gastropexy technique, muscle fold gastropexy, belt loop gastropexy. , or gastrocolopexy (RADLINSKY, 2014).

\section{Gastropexy by tube / gastrostomy}

It has the advantage of being performed quickly, allowing gastric decompression in the postoperative period. This technique is recommended after major gastric resections (WILLIAMS, 2015). However, this technique can promote peritonitis, which favors its use (PEREIRA; FANTE, 2019).

\section{Circumcostal gastropexy}

Circumcostal gastropexy has a lower percentage of recurrence than in the case of gastropexy by tube. It is a technically challenging procedure. Despite producing a strong fixation, complications such as rib fracture or pneumothorax can occur. Being more specific in prophylactic gastropexy than in emergency cases (PEREIRA; FANTE, 2019; WILLIAMS, 2015).

\section{Gastropexy in "belt loop"}

Belt loop gastropexy is the fastest and most technically simple method, it promotes excellent fixation and can be used in both emergency and elective cases (WILLIAMS, 2015). The technique is the modification of circumcostal gastropexy, the only difference being the use of the transverse abdomen muscle instead of a rib (RADLINSKY, 2014).

\section{Incisional gastropexy}

It is also an absolutely quick and simple technique based on permanent fixation between the incisional extremities of the transverse abdomen muscle and the seromuscular layer in the pyloric antrum (WILLIAMS, 2015). 


\section{Postoperative care}

Fasting from 8 to 12 hours postoperatively is necessary. After starting with small amounts of oral fluids (BRUCHIM, KELMER, 2014). Within 12 to 24 hours, offer small amounts of a light diet if there is no evidence of vomiting (SILVA et al., 2012). In addition to diet, fluid therapy, heart rate monitoring with electrocardiogram (ECG) and antibiotics, in an attempt to decrease endotoxemia (CARRILLO et al., 2016; SIMPSON, 2017). While Carrillo et al. (2016) and Simpson (2017) advocate the use of flunixin meglumine to reduce the synthesis of prostaglandins and mitigate the endotoxic effects, even if their use is risky because it can induce gastric ulceration.

\section{Postoperative complications}

Some complications can occur after surgical treatment of GVD. Most of them are secondary to the initial physiological effects of the syndrome and gastric ischemic injury. Among the complications are septicemia, peritonitis, gastritis, disseminated intravascular coagulation, cardiac arrhythmias, ischemia-reperfusion injury and acute renal failure (BRUCHIM, KELMER, 2014; CARRILLO et al., 2016).

\section{Ventricular arrhythmias}

An estimated $50 \%$ of dogs with GVD have ventricular arrhythmias, which usually occur between 12 to 72 hours after the initial presentation and are related to myocardial ischemia. This occurs due to a decrease in cardiac output associated with a reduction in splanchnic venous return, and consequently in effective coronary perfusion (SILVA et al., 2012).

If the arrhythmias interfere with the cardiac output (assessed by means of weak peripheral pulses), present subsequent premature beats inscribed in the wave of the anterior complex ( $R$ in $T$ ) or have a long-term ventricular rate greater than 160 beats per minute (bpm), should be addressed. Administer lidocaine boluses intravenously (bolus of $2 \mathrm{mg} / \mathrm{kg}$, up to $8 \mathrm{mg} / \mathrm{kg}$ of total dose) to determine responsiveness to this drug (RADLINSKY, 2014). Alternative therapeutic protocols to the use of lidocaine include the use of procainamide (can be administered as an intravenous bolus by continuous infusion, intramuscular or orally) and sotalol (only orally, effective when animals do not respond to lidocaine or procainamide) (RADLINSKY, 2014). Also according to Radlinsky (2014), arrhythmias may still be linked to hypokalemia, which, when corrected, obtains the resolution of this clinical sign.

\section{Hypokalemia}

Hypokalemia is the most common electrolyte imbalance. This event can contribute to the appearance of cardiac arrhythmias. There are several causes related to potassium losses, gastric hypersecretion, renal losses, prolonged fluid therapy, intubation and orogastric lavage, regurgitation of pancreatic and biliary secretions, the passage of potassium from the extracellular compartment to the intracellular secondary to acid-basic imbalances, anorexia, vomiting, in addition to the low potassium diet (SILVA et al., 2012). Adequate supplementation with potassium chloride is administered (RADLINSKY, 2014).

\section{Anemia}

After correction of GVD, the hematocrit tends to decrease (less than $32 \%$ ), developing anemia. This can occur due to an important preoperative blood loss, due to the avulsion of the left gastric and epiploic branches, along the greater curvature of the stomach and, during the operation, significant blood loss can occur secondary to gastropexy, gastrectomy or splenectomy (SILVA et al., 2012). 


\section{Shock}

Shock after surgery may be due to inadequate treatment, during the patient's stabilization period, hypovolemic shock, in combination with the hypotensive effect of various anesthetic drugs, of bleeding during the operation (SIMPSON, 2017; WILLIAMS, 2015).

\section{Hypoproteinemia}

It results from the abundant loss of protein secondary to inflammation, associated with peritonitis or gastritis, or ulceration of the gastric mucosa causing transudation of protein and sequestration in the gastric lumen (RASMUSSEN, 2007). Patients with serum total protein levels between 3 and $3.5 \mathrm{~g}$ dl-1 should receive fresh plasma or synthetic colloid expanders (SILVA et al., 2012).

\section{Injury to gastric mucosa and perforation}

Lesion to the gastric mucosa is a common complication observed in the postoperative period of VGD (RADLINSKY, 2014; RASMUSSEN, 2007). The lesion can vary from mild mucosal edema, to huge areas of necrosis, ulceration and perforation. The gastric site normally affected by perforation is the major curvature, in the regions of the fundus and body. The etiology is still unknown, although, suppose they are associated with ischemic injury due to reperfusion. The free radicals derived from oxygen released in the body can be the triggering factor of the injury. Authors suggest that this event is partially responsible for the morbidity and mortality associated with GVD (SILVA et al., 2012). It is extremely common for patients to develop gastritis secondary to ischemic mucosal damage (RADLINSKY, 2014).

\section{Prognosis}

According to Radlinsky (2014), the prognosis is good as long as the surgical intervention is performed at an appropriate time, with mortality rates of $45 \%$, however there are rates of up to $10 \%$ of mortality that are being reported and are becoming more common. The simple torsion has a better prognosis than the VGD. While Pereira and Fante (2019) report that the prognosis of this pathology is considered bad if there has been necrosis, gastric perfusion or even if gastrectomy has occurred, and in other conditions it has a poor prognosis. For Radlinsky (2014) the degree of rotation of the stomach is not associated with death of patients with GVD, in case of perforation or gastric necrosis the prognosis is modified and becomes reserved (BRUCHIM, KELMER, 2014; RADLINSKY, 2014). The elevation of serum lactate concentrations is a good predisposing factor for gastric necrosis, and the finding of low plasma lactate concentrations is a good prognostic indicator (GADDINI et al., 2018; RADLINSKY, 2014).

\section{Prevention}

Postprandial gastric distention should be reduced by moistening dry diets, dividing the daily portion of food into two to three smaller meals and limiting activity before and after feeding to reduce aerophagia. It is extremely important to educate the owner regarding clinical signs of dilation and the immediate need for emergency care, as well as avoiding the use of animals with a history of VGD for breeding (SIMPSON, 2017). Pereira and Fante (2019) still report the importance of the feeding bowl not being elevated, and animals with a history of this pathology should not be used as breeders, as well as performing preventive gastropexy in animals at high risk of developing gastric dilation syndrome. 


\section{FINAL CONSIDERATIONS}

Gastric volvulus dilatation is an acute clinical and surgical condition, of a not fully established etiology, with a high risk of death. Due to its acute nature, the early identification of changes, the interpretation and choice of the correct therapy are essential for the successful maintenance of the patient's life. Although the literature diverges on the first procedure to be instituted, to decompress or expand volume, as it is an emergency, both must be instituted simultaneously, otherwise, the most important for each patient must be adopted first. Surgical treatment is recommended for practically all cases, but the technique that will be used is the surgeon's choice. Prophylactic gastropexy and castration of the patient with gastric syndrome and dilation should be performed. Post-operative management of the animal and the orientation of the owner are also extremely important factors for the life of the animal, as a well-informed owner quickly perceives clinical signs, as well as prevents the VGD from happening. Making the appropriate management of the animal will may provide longer survival times for affected animals. The understanding and perception of pathophysiology directly influences the patient's prognosis.

\section{REFERENCES}

BRUCHIM, Y.; KELMER, E. Post operative management of dogs with gastric dilatation and volvulus. Topics in Companion Animal Medicine, v.29, n.3,p.81-85, 2014. Disponível <https://www.sciencedirect.com/science/article/abs/pii/S1938973614000385?via\%3Dihu b>. DOI:10.1053/j.tcam.2014.09.003

CARRILLO, J.D.; ESCOBAR, M.T.; MARTÍNEZ, M.; GIL-CHINCHILLA, J.I.; GARCÍAFERNÁNDEZ, P.; et al. Síndrome de dilatación-vólvulo gástrico (VGD). Clínica Veterinaria de Pequeños Animales, v.36, n.3, p.163-177, 2016. Disponível em: <https://www.clinvetpeqanim.com/img/pdf/1597546307.pdf>. Acesso em: 18/03/2020.

ELLISON, G.W. O estômago. In: WILLIAMS, J.M.; NILES, J.D. BSAVA Manual de cirurgia abdominal em cães e gatos. 1 ed. São Paulo: MedVet, 2015.

GADDINI, L.V.; ALENCAR, C.R.K.; TAFFAREL, M.O. USO DO LACTATO PARA AUXÍLIO NO PROGNÓSTICO DE PACIENTES CRÍTICOS. Enciclopédia Biosfera, Centro Científico Conhecer - Goiânia, v.15 n.28; p.916-923. 2018. Disponível em: <http://www.conhecer.org.br/enciclop/2018B/AGRAR/uso\%20do\%20lactato.pdf>. DOI: 10.18677/EnciBio_2018B75

GALVÃO, A.L.B.; COSTA, P.F.; ONDANI, A.C.; D’ALKIMIN, F. SÍNDROME DILATAÇÃO VOLVO GÁSTRICA - REVISÃO LITERÁRIA. Revista Científica Eletrônica de Medicina Veterinária, v.8, n.15, Jul., 2010. ISSN 1679 7353. Disponível em: $<$ http://faef.revista.inf.br/imaqens arquivos/arquivos_destaque/v5DSSHV7AMtStAl_201 3-6-25-16-24-50.pdf>. Acesso em: 10/03/2020.

GOMES, M. S.: SOUSA. J. M.: ARAÚJO, S. B.: SILVA. F. L.: LIMA. R. T: et al. Torcão primária do baco em cães: Relato de caso. PUBVET Medicina Veterinária e Zootecnia,v.11, n.9, p.917-922, Set., 2017. Disponível em: <http://www.pubvet.com.br/artigo/4012/torccedilatildeo-primaacuteria-do-baccedilo-emcatildees-relato-de-caso>. DOI: HTTP://DX.DOI.ORG/10.22256/PUBVET.V11N9.917922 
HAMMER, M.: GRAND, J.G. Gastric dilatation and volvulus in a 5-month-old Bernese mountain dog. The Canadian Veterinary Jounal, v.60, n.6, p.587-590, Jun., 2019. Disponível em: <https://europepmc.org/article/med/31156256>. Acesso em: 02/04/2020.

KÖNIG, H.E. Anatomia dos animais domésticos : texto e atlas colorido [recurso eletrônico] / Horst Erich König, Hans-Georg Liebich ; tradução: Régis Pizzato ; revisão técnica: Luciana Silveira Flôres Schoenau, Marleyne José Ảfonso Accioly Lins Amorim. 6 ed. Porto Alegre: Artmed, 2016.

LEVINE, M.; MOORE, G.E. A time series model of the occurrence of gastric dilatationvolvulus in a population of dogs. Biomed Central Veterinary Research. v.5, n.12, p.16 , 2009.

Disponível

em:

<https://www.ncbi.nlm.nih.gov/pmc/articles/PMC2679001/?tool=pubmed>.

DOI: $10.1186 / 1746-6148-5-12$.

NELSON, R.W.; COUTO, C.G. Dilatação gástrica/vólvulo. In: NELSON, R.W.; COUTO, C.G. Fundamentos de Medicina Interna de Pequenos Animais. 3 ed. Rio de Janeiro: Elsevier, 2005.

ORTIZ, B.C.; OLIVEIRA, C.M.; TEIXEIRA, L.G.; KOCH, M.C.; MULLER, V.S. Torção esplênica primária em um cão: relato de caso. Arquivo Brasileiro de Medicina Veterinária e Zootecnia, Belo Horizonte, v.68, n.5, p.1195-1200, out. 2016. Disponível em: <http://www.scielo.br/scielo.php?pid=S010209352016000501195\&script=sci_arttext>. DOI: http://dx.doi.org/10.1590/1678-41628817

PINTO FILHO, S.T.L.; DALMOLIN, F.; OLIVEIRA, M.T.; SOUZA, F.W.; SPRADA, A.G.; et al. Associeted laparoscopic-assisted gastropexy and ovario histerectomy in a Great Dane bitch. Ciência Rural. Santa Maria, v. 45, n.2, p.280-283, Feb. 2015. Disponível em: $<$ http://www.scielo.br/scielo.php?script=sci_arttext\&pid=S0103$84782015000200280 \& \operatorname{lng}=$ en $\&$ nrm $=$ iso $>$. $8478 \mathrm{cr} 20140049$.

PEREIRA, M.; FANTE, T.P. SÍNDROME DA DILATAÇÃO VÓLVULO-GÁSTRICA EM CÃES - REVISÃO DE LITERATURA. Revista Cientifica de Medicina Veterinária ,v.16,n.33, Jul. 2019. ISSN 16797353. Disponível em: <http://faef.revista.inf.br/imaqens arquivos/arquivos_destaque/M1ePpPQeoi585p3_201 9-10-21-9-22-10.pdf >.Acesso em: 31/03/2020.

RADLINSKY, M.G. Cirurgia do Sistema Digestório: Cirurgia do Estômago. In: FOSSUM, T.W. Cirurgia de Pequenos Animais. 4 ed. Rio de Janeiro: Elsevier, 2014.

RASMUSSEN, L. Estômago. In: SLATTER, D. Manual de Cirurgia de Pequenos Animais . 3 ed. Barueri: Manole, 2007.

SILVA, G.; SILVA, H.R.; D'AMICO, L.R.; ALVES, M.B.L.; GUERINO, W.L.; et al. Síndrome dilatacão vólvulo gástrica - revisão de literatura. Ciência Veterinária UniFil, v. 1, n. 3, p.58-65, mar. 2019. ISSN 2595-7791. Disponível em: <http://periodicos.unifil.br/index.php/revista-vet/article/view/984>. Acesso em: 10/03/2020.

SILVA, S.S.R.; CASTRO, J.L.C.; CASTRO, V.S.P.; RAISER, A.G. Síndrome da dilatação ENCICLOPÉDIA BIOSFERA, Centro Científico Conhecer - Jandaia-GO, v.17 n.34; p. 256 
vólvulo qástrica em cães. Ciência Rural, Santa Maria, v.42, n.1, p.122-130, 2012. Disponível em: $<$ http://www.scielo.br/scielo.php?pid=S0103-

$84782012000100020 \&$ script=sci_arttext $>$. DOI: https://doi.org/10.1590/S010384782012000100020

SIMPSON, K.W. Diseases of the Stomach. In: ETTINGER, S.J.; FELDMAN, E.C.; CÔTÉ, E. Textbook of VETERINARY INTERNAL MEDICINE. 8 ed. St. Louis, Missouri, USA: Elsevier Saunders, 2017.

UZAL, F.A.: PLATTNER, B.L.: HOSTETTER, J.M. Alimentarv Svstem. In: MAXIE. M.G. Jubb, Kennedy and Palmer's Pathology of Domestic Animals. 6 ed. St. Louis, Missouri, USA: Elsevier Saunders, 2016.

WILLIAMS, J.M. Dilatação e torção gástrica. In: WILLIAMS, J.M.; NILES, J.D. Dilatação e torção gástrica. BSẢVA Manual de cirurgia abdominal em cães e gatos. 1 ed. São Paulo: MedVet, 2015. 